\title{
Measuring technological capabilities in Mexican industry
}

\author{
Lilia Dominguez and Flor Brown
}

$\mathrm{T}$

his paper is a methodological and analytical contribution to a line of research whose objective is to construct representative indices of the technological capabilities of Mexican manufacturing establishments. It also examines the distribution of these capabilities in such establishments and their association with performance variables in a sample of 1,818 firms. Factor analysis was used to identify four factors expressing the main sources of learning in manufacturing industry: i) training policy, ii) continuous improvement innovation, iii) information and documentation systems, and iv) investment in new technologies. Grouping analysis was used to identify four groups of establishments on the basis of points scored per factor and to examine their performance indicators. There was found to be a positive association between technological capabilities and performance in three of the five indices: profit margins, labour productivity and technical change.

Flor Brown

- brown@servidor.unam.mx

Postgraduate Professors at the Faculty of Economics, Universidad Nacional Autónoma de México (Unam) 


\section{I}

\section{Introduction}

There is increasing agreement that the heterogeneity of businesses in developing countries has major consequences. This paper argues that analysing the technological capability levels of establishments is useful for understanding the origins of the differences they display. These differences play a central role in evolutionary process theory, which highlights the importance of learning in the generation of technical change (Nelson and Winter, 1982). According to this theory, individuals, establishments and national economies will create and gain access to wealth in accordance with their learning capacity (Lundvall, 1992). It calls into question the simplistic view that the meaning of technology comes down to machinery or manuals setting out the steps to be followed. On the contrary, what technology means above all is the transmission of knowledge between different agents; it is characterized by having tacit components of knowledge specific both to individuals and to the internal practices of the business generating it; and it is developed through seeking and learning procedures whose aim is to improve production efficiency, generate new products and introduce organizational methods. By contrast with traditional approaches, it is argued, technological development in industry should not be seen as a process that can only be driven by investment in new equipment and imported technology. For technology to be assimilated, properly operated and improved, establishments need to execute deliberate technological learning investments and actions. Consequently, it is not enough just to buy machinery or arrange for technology transfer to narrow the international technology gap. Establishments need to research the technology, understand it and document it if they are to absorb and improve it.

Similarly, Bell and Pavitt (1992) cast doubt on the distinction between innovation and dissemination. They argue that dissemination entails far more than acquiring machinery and the technological know-how that goes with it, as it also involves continuous and often incremental technical change to adapt to specific situations and attain higher performance standards. They distinguish three stages in the dynamic of technical change in developing countries: in the first, technology is adopted through the incorporation of new equipment and then the original technology is adapted or improved as the specific situation requires; in the second, there is an effort to improve on the initial level of efficiency and the technology is modified in response to changes in input and product markets. The two stages described require a continuous accumulation of knowledge and skills. In the third stage, establishments can draw on the know-how, experience and new skills acquired to introduce more substantial technical change. The authors cited define technological capabilities as the skills needed to generate and administer technical change, including techniques, know-how and experience different from those required to operate technical systems.

Numerous studies show that the ability to learn and accumulate technological capabilities is what underlies the competitiveness of highly developed countries (Lundvall, 1992). It has also been shown that the export success of South-East Asian manufacturers, particularly those of Korea and Taiwan, has been built not only on systems of market policy or technology imports, but also on the range of strategic measures introduced alongside these to increase the learning capacity of firms (Pack and Westphal, 1986; Fransman and King, 1984; Amsden, 1992). In the case of Latin America, there are now a number of studies showing, for certain sectors of industry, how technological learning takes place in establishments and what effects it has on modernization (Katz, 1997 and 1987). Cimoli (2000) analysed different aspects of the national innovation system in Mexican industry.

The evidence provided by these studies is valuable, as they were the first to examine the conditions required for innovation in a systemic, detailed way. Thanks to them a diagnosis is now available of the establishments that have most influence on the economy and that constitute one of the pillars of the national innovation system. Nonetheless, while there are studies dealing with the construction of indicators using different sources and methodologies, there has been less progress in constructing companylevel indicators derived from samples of a significant size; this might enable the accumulation of 
technological capabilities to be elucidated with accuracy. ${ }^{1}$ These indicators of technological capabilities in establishments could help to determine, more precisely than case studies can, the factors underlying the differences between establishments and the effects these have on their performance.

This paper aims to make progress in this direction, i.e., to develop indicators that can be used to measure technological capabilities in Mexican industry. ${ }^{2}$ The idea is to identify the learning activities that most contribute to the capacity to administer and generate technical change in Mexican manufacturing establishments. The challenge lies in the difficulty of capturing the concept of technological capabilities in all its complexity, as it covers many different aspects. This means that some method has to be used to achieve a degree of simplification. We believe that the right statistical technique is factor analysis, which can represent relationships between sets of interrelated variables and explain complex concepts without imposing a predetermined structure. The objective is to provide tools for the analysis of technological capabilities by means of one or more indices, drawing on the work of Bell and Pavitt (1992) and Lall (1992). ${ }^{3}$

A second objective of this study is to identify clusters or groups of establishments by technological capability level, with a view to ascertaining the extent to which the levels of each group are associated with significant differences in performance.

This paper has five sections. This introduction (section I) is followed by a brief review of recent studies on the construction of technology indices (section II). The methodology that was used to prepare the technological capability indices is described in section III. Section IV analyses these indices and the characteristics of the groupings of industrial enterprises created on the basis of the indices calculated, and presents some performance measures for groups with different technological capability levels. Lastly, section $\mathrm{V}$ presents the conclusions.

\section{II}

\section{Constructing technology indicators or indices: recent contributions}

This section will review some of the most influential studies in this area. They present different ways of quantifying the technological capabilities of establishments, along with estimates for composite indices. Many of these studies draw on the work of Bell and Pavitt (1992) and, in particular, the taxonomy devised by Lall (1992), who suggests ways of classifying the technological capabilities developed by establishments with a view to assimilating, adapting and improving the technology acquired. This taxonomy distinguishes between investment, production and linkage capabilities. For Lall, investment capabilities are the skills needed to identify, prepare and obtain technology for the design, construction, equipping and staffing of a new project. The capital costs of the

\footnotetext{
${ }^{1}$ Authors such as Tremblay (1998) and Romijn (1999) have drawn attention to the need for robust indicators.

${ }^{2}$ We are grateful for the participation of the National Institute of Statistics, Geography and Information (INEGI) in the company-level estimation work.
}

project depend on the scale of production, the composition of the range of goods produced, the technology chosen and the company's understanding of the technologies involved. Production capabilities range from basic skills (quality control, operation, maintenance) to the most advanced ones (adaptation, improvement) and the most demanding (research, design, innovation). These skills enable a business not only to operate and improve technologies, but also to make the internal effort needed to absorb or imitate the technology purchased from other establishments. Linkage capabilities are the skills needed to swap information, technology and skills between establishments (suppliers, subcontractors, consultants, technology institutions); they affect both the productive efficiency of the company and the dissemination of technology in the industry, and they may be developed at different levels. At the primary level the company

\footnotetext{
${ }^{3}$ See section III for a more detailed explanation of factor analysis.
} 
acquires basic skills, at the intermediate level it achieves secondary skills (i.e., imitation) and at the highest level it attains the highest innovation capabilities.

Some research seeking to identify establishments' sources of learning and technological activities are based on surveys conducted especially for this purpose, others on official statistics. The first group includes the following studies: Westphal, Kritayakirana and others (1990), which used a sample of 100 Thai establishments; Lall and others (1994), using the case of four industries in Ghana; Romijn (1999), centred on the Pakistani capital goods industry; Wignaraja (2001), with a sample of textile and clothing firms in the Mauritius islands, and Tremblay (1998), based on a sample of the Canadian paper industry. The complexity of the aspects analysed to construct the index differs from study to study.

Romijn (1999), for example, measures technological capabilities with reference to the degree of complexity involved in the production of the goods concerned, basing her approach on the learning mechanisms of the small-scale metal-working industry. She argues that "upward diversification" in that industry takes place through a learning process involving the imitation of designs and reproduction of goods whose manufacture is of increasing complexity, so that with a given stock of machinery and equipment it is possible to make different products, with different degrees of complexity, depending on the technical level of the operations carried out; consequently, the manufacture of the different products made using the same stock of machinery may require differing degrees of skill. The work cited develops a production capability indicator, rather than an innovation or investment indicator; gathers a sample of 50 products made by local industry; designs a system to identify the level of production capabilities incorporated into each good, and classifies the degree of technological complexity (skills and know-how) of each of the operations needed to make the product.

Wignaraja's (1998 and 2001) technology index takes Lall's taxonomy, but is estimated on the basis of two technological capabilities, those of production and linkage, owing to the lack of data on investment capabilities. He examines 40 establishments in the garment industry by means of a survey. The production capabilities category is represented in the scoring system by 10 technical activities that range from the common tasks of process engineering (rejection rates, whether or not the ISO 9000 industrial quality standard applies) to those of product engineering (copying, improvement or introduction of new products).
Productivity improvements were also included in this category. The category of linkage capabilities is represented by two technical activities: technology transfer through subcontractors and through contact with corporate customers abroad, respectively. Each of the 12 technical activities mentioned can be graded into different levels, which in turn reflect different levels of competence in this capability. Thus, the position occupied by a company will depend on how many points it scores out of a maximum of 24 , this result then being normalized to between 0 and 1 .

Lastly, Tremblay (1998) measures the technological capabilities ${ }^{4}$ of the paper industry in Canada and India, to see how these capabilities are associated with total factor productivity. He is critical of other studies for failing to distinguish between technological and production capabilities, as this produces a narrow view of their composition, particularly in Romijn's work. Tremblay also examines the importance given to the technological capabilities of human resources and the neglect of these in the structure of groups and in the organizations where individuals work. Lastly, he notes that most studies do not include generation capabilities or measurements of technological change. In Tremblay's research, human resources, skills and human capital were evaluated by formal aspects, such as the number of employees working in technical activities and their educational level (whether they had a degree or better). Two rates were used: the number of graduates as a proportion of the whole workforce and the number of graduates as a proportion of sales. Using a Likert scale, efforts to change (or the organization's involvement with change) were measured using four variables: scale, intensity, role and responsibility. The scale variable evaluated the relationship between the number of individuals involved with change and the total number of individuals employed. The intensity variable evaluated the frequency with which activities that generated technical change were carried out. The role variable was defined by the type of activities performed (problem solving, implementation, generation). Lastly, the responsibility variable evaluated the involvement with change of each member of the organization.

\footnotetext{
${ }^{4}$ In Latin America, efforts to carry out measurements of this type have been made in Colombia, where a survey of technological development in industry, the Encuesta sobre Desarrollo Tecnológico en la Industria Colombiana, has been held. As of the date of this study, however, no results measuring technological capabilities could be found.
} 
There are other studies that use census information or official statistics. This is the case with Yan Aw and Batra's (1998) study of Taiwanese industry. These authors use specific characteristics of establishments, such as research and development activities and in-plant training, to quantify their efforts to assimilate the technology acquired. They also consider other variables to be sources of knowledge, such as the presence of foreign direct investment, the use of foreign patents and contact with international customers through exports. They introduce these characteristics into a frontier production function in order to carry out a consistent analysis of the correlation between a company's efficiency and its investments in research and development, training and international linkage. The study we are analysing recognizes the evidence offered by Westphal, Rhee and Pursell (1984) on the importance of foreign customers in technology transfer. Yan Aw and Batra assume that this acquisition of technical know-how occurs through exporting. Thus, rather than estimating a composite index, they carry out the analysis in two steps. They distinguish two groups of establishments, those that export and those that do not, and they then estimate frontier production functions for them both with a view to evaluating the contribution made to efficiency by the different learning activities.
Lastly, Dutrenit and Capdevielle (1993) examine developments in manufacturing, using Pavitt's (1984) classification of technology paths, which includes an evaluation of the technological capabilities of establishments. For this they use three variables: average pay (as a proxy for the technology of skills), investment in machinery and equipment (as a proxy for hard technology) and research and development (as a proxy for soft technology).

In constructing their capability indices, the studies we have discussed here were confronted with enormous information difficulties, as they themselves readily acknowledge, and worked largely with proxies. Our study attempts, insofar as information is available, to adhere closely to the taxonomy proposed by Lall (1992).

Our task will be to simplify the vast array of indicators in the National Survey of Employment, Wages, Technology and Training (Encuesta Nacional de Empleo, Salarios, Tecnología y Capacitación, ENESTYC) $)^{5}$ to arrive at a few representative indicators. The survey provides a number of variables whose importance for technological capability-building is uncertain. It seems to us wrong to estimate a composite index that gives the same weighting to them all. At the same time, weighting them subjectively in the absence of other evidence does not seem acceptable either. As was noted at the beginning, we believe that factor analysis is the right statistical technique in this case.

\section{III}

\section{Methodology and information sources}

Any measurement requires an instrument and an agreed standard. The production variable is measured in tons or units, returns as a percentage of the capital invested, and cost in monetary units. The variables we are using in this study cannot be measured in this way, since their conceptual complexity means that they cannot be observed directly and in isolation. The challenge is a considerable one, but it is possible to approach technological capabilities by constructing variables that can be observed directly.

The methodology applied in this study is a multivariate analysis. The multivariate techniques considered initially were principal components or factor analysis. While principal component techniques are better for deriving a small set of linear combinations from the original variables that represents the whole of the variance, factor analysis techniques can be better for making qualitative distinctions (Schilderinck, 1970; Tabachnick and Fidell, 2001). For this reason it was decided that factor analysis would be used.

A factor is a qualitative dimension in an axis of coordinates: it defines how entities differ, just as the size or taste of an object defines a qualitative dimension. Factor analysis gives the data a dimensional structure, in that it indicates the common characteristics they possess.

\footnotetext{
${ }_{5}^{5}$ Conducted by the Mexican National Institute of Statistics, Geography and Information (INEGI).
} 
With this analysis, a formal model is specified that describes each variable by means of a few common non-observable factors and a single latent factor.

This last is based on the assumption that there are a number of causal factors which give rise to different relationships between the variables. Other names for these factors are component, conditioning or dimension factors. Their number is considerably smaller than the number of relations. In other words, factor analysis reveals common dimensions, or factors that link them through variables that are apparently unrelated; consequently, it provides insights into the underlying structure of the data.

The large number of variables involved in the construction of technological capability indices complicates the analysis and makes it harder to draw the conclusions needed to produce these indices. Through factor analysis we hope to find a small number of variables that express the main elements conditioning learning in Mexican manufacturing industry.

Formally speaking, factor analysis involves the selection of a small number of common factors that reconstruct a large number of variables:

$$
Z_{i j}=\sum_{p=1}^{h} F_{i p} a_{p j}+e_{i j}
$$

where

$Z=$ the variables observed

$F=$ the common factors of $Z$ that are not directly observable

$e=$ the single factor analogous to the residual in regression analysis

$a=$ the constants used to combine the $k$ factors or load coefficients. These coefficients indicate the weight assigned to each factor.

The factors can be inferred from the variables observed and can be estimated as a linear combination of these in the following way:

$$
F_{p i}=\sum_{j=1}^{k} q_{p j} z_{j i}
$$

where

$F=$ the value of the factor

$q=$ the load coefficient

$Z=$ the variables observed.

The above expression shows the presence of common patterns of movement between two or more of the variables being examined. These patterns are expressed in coefficients called factor loads that indicate the extent to which the variances of the variables concerned are represented in this coefficient by a factor. In turn, this factor is common to the variables forming part of a specific pattern of movement (Schilderinck, 1970).

\section{The information sources}

Two sources were used for this study: the ENESTYC and the Annual Industrial Survey (Encuesta Industrial Anual, EIA). ${ }^{6}$ The ENESTYC contains nationally representative information on the characteristics of manufacturers' technology and productive organization, amount and type of employment generated, occupational structure, pay and training. Its database covers 8,181 establishments. It includes all large and medium-sized firms and a random sample of small firms and microenterprises. The EIA, meanwhile, covers 6,675 businesses in 200 classes of industry. It provides statistical information on the behaviour of the main economic variables in the manufacturing sector, including staff numbers, pay, current operating costs and expenditure, electricity use, output and net sales, and assets.

The variables used to measure technological capabilities were obtained from the 1999 ENESTYC. This survey contains 115 questions with about 570 reply options. Of these an initial selection was made of 50 questions with their reply options, approximating to the capabilities identified by Lall (1992). These were used as a basis for constructing 26 variables relating to investment, production and linkage between establishments and institutions.

The company learning and investment variables are five in number: purchases of technology packages or technology transfer from the parent company, investments in management technology, investments in basic engineering, investments in patents, and recruitment policy.

For efforts towards change in the production sphere, the following variables were considered: i) research and development, ii) organizational improvements, iii) progress with quality certification, iv) the use of preventive and predictive maintenance, v) the existence of documented practices and norms,

\footnotetext{
${ }^{6}$ Like the ENESTYC, the EIA is conducted by the National Institute of Statistics, Geography and Informatics (Instituto Nacional de Estadística, Geografia e Informática-INEGI).
} 
vi) the introduction of new technologies, vii) technical consultancy, and viii) the intensity of training at the four levels of employment: managerial staff, clerical staff, skilled workers, and general workers.

Inter-company linkage activities were captured in five variables: i) sales or purchases, ii) research and development, iii) training, iv) use and acquisition of machinery and equipment, and v) measures to create linkages with universities or other institutions.

Lastly, following Yan Aw and Batra's (1998) analysis of technological capabilities in Taiwanese industry, company exports were taken as a proxy variable for the technological information obtained from customers abroad. This can be applied to certain types of firm, such as part and component makers, those that work under franchises, and maquila establishments, ${ }^{7}$ but it does not hold good for all establishments that export. We believe it is important to include this variable to complete the linkage capability indicators.

The variables relating to the characteristics of the industrial structure or dynamic were constructed using EIA information for the years from 1993 to 1998 . These variables are reflected in the following indicators: factor and labour productivity, average company size, and foreign direct investment as a share of the company's capital and gross output.

A sample was constructed with information combined from the two surveys, identifying a total of 1,818 establishments. Of these, $73 \%$ are medium-sized

\section{IV}

\section{Results}

\section{Estimation of technological capability indices}

The outcome of the factor analysis carried out with the variables described is given in table 1 . This identifies four factors (columns A, B, C and D) with a characteristic value of more than one. Use was made of the Varimax rotation method, which seeks to

\footnotetext{
${ }^{7}$ Among industries whose exports involve a direct relationship with the customer, most of which are in the maquila sector, mention should be made of those which make parts and components for motor vehicles, household electrical equipment and computers. In other industries, however, strategic alliances are often entered into with foreign establishments for marketing purposes, and these perform the knowledge transfer function.
}

enterprises (between 100 and 500 employees), of which 265 have foreign capital. In the sample, this group accounts for $34 \%$ of gross output, $15 \%$ of exports and $45 \%$ of staff. There are 371 large establishments (over 500 employees), of which 115 have foreign capital. This group accounts for $65 \%$ of gross output, $84 \%$ of exports and $53 \%$ of staff. As can be seen, mediumsized and large enterprises are well represented in the sample, but smaller establishments are not.

Many of the variables are binary in nature, because that is how the survey recorded them. Some of them cover more than one aspect. For example, the organization variable corresponded to the question about the possible adoption of changes in the company, such as a just-in-time system, job rotation, changes in plant lay-out and so on. A positive response to any of these was worth a point. The more changes the company notified, the more points it obtained for this variable. The variables captured in quantitative form were estimated as percentages and given ranges. ${ }^{8}$

To arrive at the results, a number of factor analysis exercises were carried out to eliminate variables that had very low factor loads on their respective factors. The variables eliminated were investment in management technology, basic engineering and technical assistance; investment in the use of patents, and the different linkage activities (except for contact with foreign customers through exports, relationships with universities and research centres, subcontracting and joint ventures). minimize the number of variables that have large loads on one factor. Higher factor loads have a greater association with the corresponding variable. This factorial matrix can be used to interpret a company's capabilities in four dimensions of learning that bring together our variables. Column $\mathrm{E}$ of the table shows the communality coefficients. ${ }^{9}$

\footnotetext{
${ }^{8}$ See appendix A for further details on the construction of variables.

9 This information is essential in factor analysis; the same is not true of the principal components method, which yields the percentage of the variance explained. As Dillon and Goldstein (1984) argue, principal components analysis is a variance analysis, while factor analysis focuses on the amount of variance that each variable shares with the others. Consequently, factor analysis is a covariance analysis.
} 
Mexico: Results of factor analysis, 1999a b

\begin{tabular}{|c|c|c|c|c|c|}
\hline & \multicolumn{4}{|c|}{ Factor } & \multirow{2}{*}{$\begin{array}{l}\text { Communality } \\
\text { coefficient }^{\mathrm{c}}\end{array}$} \\
\hline & $\begin{array}{c}\text { Training } \\
\text { policy } \\
\text { (A) }\end{array}$ & $\begin{array}{l}\text { Continuous } \\
\text { improvement } \\
\text { innovation } \\
\text { (B) }\end{array}$ & $\begin{array}{l}\text { Information and } \\
\text { documentation } \\
\text { systems } \\
\text { (C) }\end{array}$ & $\begin{array}{l}\text { Investment } \\
\text { in new } \\
\text { technologies } \\
\text { (D) }\end{array}$ & \\
\hline Organizational changes & 0.01 & 0.40 & 0.16 & 0.11 & 0.20 \\
\hline Changes in quality certification and systems & 0.05 & 0.46 & 0.12 & 0.07 & 0.23 \\
\hline Technology purchases & -0.04 & 0.47 & 0.07 & 0.03 & 0.23 \\
\hline Recruitment policy & 0.13 & 0.28 & 0.12 & 0.15 & 0.13 \\
\hline Documentation of training programmes & 0.16 & 0.17 & 0.59 & 0.11 & 0.41 \\
\hline Documentation of security programmes and norms & 0.04 & 0.16 & 0.59 & -0.02 & 0.38 \\
\hline$\%$ trained managerial staff & 0.49 & 0.19 & 0.09 & 0.02 & 0.29 \\
\hline$\%$ trained clerical staff & 0.83 & 0.06 & 0.04 & 0.02 & 0.70 \\
\hline$\%$ skilled workers & 0.67 & 0.07 & 0.06 & 0.05 & 0.46 \\
\hline$\%$ trained general workers & 0.66 & -0.08 & 0.05 & -0.04 & 0.45 \\
\hline Contact with customers abroad through exporting & 0.04 & 0.33 & 0.01 & 0.09 & 0.12 \\
\hline Introduction of $\mathrm{CNC}$ technology and robots & -0.01 & 0.15 & 0.04 & 0.65 & 0.45 \\
\hline Renewal of equipment and new technologies & 0.01 & 0.172 & 0.02 & 0.272 & 0.10 \\
\hline Research and development & 0.08 & 0.31 & 0.06 & 0.15 & 0.13 \\
\hline
\end{tabular}

Source: Authors' estimates using information from the National Survey of Employment, Wages, Technology and Training (ENESTYC), 1999.

\footnotetext{
a Extraction method: principal axis factoring. Varimax rotation with Kaiser normalization. The rotation converged after five repetitions.

b Bold type is used to highlight high factor loads.

c The communality coefficients measure the relationship between the variance of each variable and the variance of the remaining variables.
}

Column A of table 1 reveals high factor loads in the percentages of trained staff at the four employment levels: managerial staff, clerical staff, skilled workers and general workers. There is evidence that worker training is on the rise, in terms of both hours of instruction and quality, although doubtless this is not true across the board. In our opinion, this pattern of corporate behaviour is indicative of a comprehensive company training policy, whence the column heading.

Column B reveals an interesting pattern of relationships between variables: progress with quality systems and quality certification, changes in the organization of the production process, acquisition of technology packages and technology transfer, and policies for recruitment, research and development, and learning through contact with international customers as a result of exporting. The highest factor loads are for technology purchasing (0.47), changes in quality systems and quality certification (0.46), changes in work organization, learning through contact with foreign customers as a result of exporting (0.33) and in-house research and development (0.31).

Like other late industrializing countries, Mexico depends on the acquisition of technology from abroad. This variable appears to be interrelated with other learning variables that are part of what may be called continuous improvement innovation. Innovations in production processes have meant intense problemsolving efforts by establishments. The resultant activities have led to changes in the organization of production operations that may involve a new plant lay-out, the adoption of just-in-time production systems, the formation of quality circles and increased worker participation (Coriat, 1992). Again, establishments are slowly progressing towards what has been called a new culture of quality. This involves a systemic measuring approach to provide better customer service, but it also means that fewer jobs have to be repeated and costs are lower, something seen very clearly in the automotive industry (Carrillo, 1993). The production and quality departments are no longer separated but are in constant communication. The presence of the research and development variable in a company denotes its connection with efforts to assimilate, adapt and improve imported technology, as happens in similar countries, and not a stage in innovation capabilities. Lastly, learning by contact with foreign customers as a result of exporting may suggest that the flow of information is related with this continuous improvement innovation process, which in turn means that exports can grow. The variable relating to company recruitment policy mainly denotes the 
availability of the skills the business needs to bring in these changes.

In column $\mathrm{C}$, the factor loads of the variables relating to the documentation of training plans and security programmes highlight the need to develop information and documentation systems in establishments. When precise indicators are chosen, an accurate analysis can be carried out to identify critical problems, as a result of which establishments can act to find long-term solutions to these problems and follow up the results. These variables, however, are only proxies for what we term information and documentation systems. The documentation of training programmes involves a set of issues ranging from content to methods of evaluation and follow-up. Much the same is true of the documentation of security programmes. Generally speaking, establishments that undertake tasks of this kind already have more basic levels of documentation, such as formal rules and procedures.

Column D illustrates the technological effort from the point of view of hard technology use: the introduction of new technologies and the renewal of equipment. Part of the knowledge, undoubtedly, is incorporated in the machines. As these are renewed, the company acquires new knowledge and is encouraged to make complementary changes. Different studies have analysed the strong mutual relationship that exists between the application of new technologies and organizational changes (Edquist, 1992; Hoffman, 1989). A change in the organization may bring a technological change with it, or vice-versa, or the two may come in tandem and condition each other.

Column E presents the communality coefficients, ${ }^{10}$ which are fairly satisfactory. It can be seen that these are highest for training and documentation activities. The lowest coefficients (below 0.20) are for the equipment renewal, research and development and recruitment policy variables. Even so, it was decided that these variables should not be removed from the analysis because they were complementary to the factors identified.

To sum up, factor analysis can be used to distinguish the four dimensions most representative of technological learning in Mexican industrial enterprises. The variables identified for preference were those relating to the production capabilities

\footnotetext{
${ }^{10}$ As noted in table 1 , these coefficients measure the relationship between the variance of each variable and the variance of the other variables.
}

identified in Lall's taxonomy. Of the investment variables, the only ones to appear are technology purchases or acquisition of technology packages, and the policy of recruiting highly qualified staff.

It is striking that, in the linkage variable, the relationship with universities and research centres, subcontracting and joint ventures were relegated to the lowest places in the factor analysis, with a communality coefficient of less than 0.1 . A notable exception, which was considered separately from this variable, was contact with foreign customers through sales abroad. Progress has undoubtedly been made with linkage activities, and this is seen with some of the most prominent firms, but in a large sample it is not significant. In other words, the results bear out the conclusion of other authors that Mexican firms still do not have enough contact with one another or with universities (Casas, de Gortari and Luna, 2000).

\section{Cluster analysis}

The information obtained from the factor analysis was used to calculate the score for each factor in each of the observations. The factorial scores represent the relationship of the different observations with each factor, and they are high when the communality coefficients and the ratio between variables and factors are high.

The cluster analysis of establishments was conducted using the factorial scores with the " $k$ means" method. This method consists in identifying relatively homogeneous groups of cases and is based on an algorithm that minimizes the Euclidean distance between case $i$ and the average for the group containing this case. The procedure is to move the $n$ cases from one group to another until the point is reached where none of these moves reduces the error in the division, this error being the sum of the square of the Euclidean distances.

The results from our cluster analysis shown in table 2 identify a number of different patterns of capability accumulation among the establishments in the sample, on the basis of the four factors referred to earlier. The profile of the four clusters or groups identified can be summarized as follows. Group I consists of 741 establishments with $62 \%$ of the sample's gross output and $75 \%$ of its total exports. In relation to capabilities, it scores best for innovation through continuous improvement and investment in new technologies, and second best for information and documentation systems. It is composed primarily of 
large enterprises, which generate $73 \%$ of the group's gross output, and includes 204 companies with foreign capital, accounting for $52 \%$ of the sample's gross output and $78 \%$ of its exports. The businesses in this group are larger on average, as measured by gross output and exports, than those in the other three groups (tables 2 and 3).

Group II contains 169 establishments that generate $10 \%$ of the sample's gross output and exports by value. It scores best for training policy, while it has an intermediate score for information and documentation systems. As in the first group, large firms predominate, generating $70 \%$ of the sample's gross output and $90 \%$ of its exports. It includes just 29 establishments with foreign capital. The average size of businesses, as measured by gross output and exports, is $30 \%$ and $40 \%$ respectively of that of establishments in the first group (tables 3 and 4).

Group III scores best for information and documentation systems and displays no difference in

TABLE 2

Mexico: Characteristics of groups of establishments, 1999

\begin{tabular}{|c|c|c|c|c|c|}
\hline \multirow[t]{2}{*}{ Group } & \multirow[t]{2}{*}{ No. } & \multicolumn{2}{|c|}{$\begin{array}{l}\text { Average company size } \\
\text { (thousands of } 1993 \text { pesos) }\end{array}$} & \multirow{2}{*}{$\begin{array}{l}\text { Businesses } \\
\text { with FDI } \\
\text { (number) }\end{array}$} & \multirow{2}{*}{$\begin{array}{c}\text { Gross output share } \\
\text { of businesses } \\
\text { with FDI }(\%)\end{array}$} \\
\hline & & Gross output & Exports & & \\
\hline I & 741 & 272154 & 63873 & 204 & 52 \\
\hline II & 169 & 193620 & 38060 & 29 & 32 \\
\hline III & 627 & 124717 & 13577 & 141 & 37 \\
\hline IV & 247 & 61769 & 3948 & 24 & 9 \\
\hline
\end{tabular}

Source: Authors' estimates using information from the Annual Industrial Survey (EIA).

TABLE 3

Mexico: Distribution of technological capabilities

in groups of establishments, 1999

\begin{tabular}{lcccc}
\hline Group & Number & $\begin{array}{c}\text { Training } \\
\text { policy }\end{array}$ & $\begin{array}{c}\text { Continuous improvement } \\
\text { innovation }\end{array}$ & $\begin{array}{c}\text { Information and } \\
\text { documentation systems } \\
\text { new technologies }\end{array}$ \\
\hline I & 741 & -0.187 & 0.2753 & 0.2515 \\
II & 169 & 2.045 & 0.0087 & 0.1674 \\
III & 627 & -0.1799 & -0.0801 & 0.335 \\
IV & 247 & -0.5312 & -0.4853 & -1.4933 \\
\hline
\end{tabular}

Source: Authors' estimates using information from the National Survey of Employment, Wages, Technology and Training (ENESTYC).

TABLE 4

Mexico: Performance indicators, 1993-1998

\begin{tabular}{|c|c|c|c|c|c|}
\hline Group & $\begin{array}{l}\text { Profit } \\
\text { margin }\end{array}$ & $\begin{array}{c}\text { Labour } \\
\text { productivity }\end{array}$ & $\begin{array}{l}\text { Total factor } \\
\text { productivity }\end{array}$ & $\begin{array}{l}\text { Technical } \\
\text { change }\end{array}$ & Efficiency \\
\hline I & 1.150 & 1.326 & 1.008 & 1.010 & 1.017 \\
\hline II & 1.025 & 1.036 & 0.999 & 1.031 & 1.006 \\
\hline III & 0.958 & 0.943 & 1.006 & 1.002 & 0.992 \\
\hline IV & 0.867 & 0.696 & 0.987 & 0.957 & 0.985 \\
\hline Average & 1.000 & 1.000 & 1.000 & 1.000 & 1.000 \\
\hline \multicolumn{6}{|c|}{ Variance analysis } \\
\hline $\mathrm{F}$ & 9.24 & 15.63 & 1.20 & 4.77 & 0.61 \\
\hline Probability & 0.00 & 0.00 & 0.31 & 0.00 & 0.61 \\
\hline
\end{tabular}

Source: Authors' estimates using information from the Annual Industrial Survey (EIA), various years. 
other aspects. It is made up of 627 establishments generating $24 \%$ of the sample's gross output by value and $13 \%$ of its exports. There are 141 businesses with foreign capital, and these account for $37 \%$ of the sample's gross output and $51 \%$ of its exports (tables 3 and 4).

Group IV includes 281 establishments accounting for $5 \%$ of the sample's gross output and just $2 \%$ of its exports. It scores lowest for all the factors. The average company is less than a quarter as large here as in group I and considerably smaller than in groups II and III. It should be recalled here that the sample analysed consists of 1,818 establishments of the 8,181 covered by the ENESTYC, as information was not available on the performance of all of them over time. This sample is certainly skewed towards the best companies. By conducting a similar exercise for all the businesses included in the ENESTYC, it was found that group I had 1,981 establishments, group II had 869, group III had 2,014 and group IV had 3,317. Thus, if the ENESTYC is considered in its entirety, the group with the fewest capabilities accounts for $41 \%$ of all businesses and the one above it for $24 \%$.

One might have expected that in some group, particularly group I, all the factors would turn out to be positive. The fact that this was not the case in the grouping analysis does not mean that there are no companies with these characteristics. We found all four factors to be positive in 76 of the 1,818 establishments, and the same was true of 696 of the 8,181 businesses included in the ENESTYC (most of these 696 were in groups I and II). Again, the fact that group I did not stand out in the comprehensive training policy category does not mean that these businesses regard training as unimportant.

\section{Are the clusters associated with performance levels?}

To answer this question, the performance of the groups was compared in terms of gross profit margins, labour productivity, and factor productivity estimated by means of the Malmquist index, to break it down into technical change and efficiency. ${ }^{11}$ As Cantner and Hanusch (2001) argue, the use of factor productivity may seem somewhat outdated, given the criticisms of it that have arisen primarily in the context of growth accounting exercises, where the determination of factor productivity is based on assumptions of equilibrium and conditions of the traditional theory, combined with the supposition that the same production function is applicable to all the observations. The Malmquist index does not have these assumptions, and it can be used to identify both local technical change at the production frontier and such observations as fall below best practice. ${ }^{12}$ Group I, which stands out for its high indices of technological capabilities, presents the best indices of performance, except in the case of technical change, where group II does slightly better (1.031 against 1.010). ${ }^{13}$ In other words, establishments whose practices included documentation and planning, equipment and machinery renewal and complex programmes of continuous improvement perform better. Something similar happens with group II, which performs better than those below it, with one exception. This suggests there is a positive association between technological capabilities and performance.

To determine whether the differences were significant, a one-way analysis of variance was carried out, and the results of this are shown in the last two rows of table 5. The differences observed are significant in three of the five indices: profit margin, labour productivity and technical change, which supports the hypothesis that technological capabilities are a decisive element in innovation and company performance. An analysis of the variance between any one group and the others (Scheffe test) confirms that the largest gaps are between group I and group IV, which is in last place. ${ }^{14}$

\footnotetext{
${ }^{12}$ See Cantner and Hanusch (2001) for a full analysis of the use of the Malmquist index in a context of heterogeneity and evolutionary change.

${ }^{13}$ The indices were normalized in relation to the averages for the sample.

${ }^{14}$ See appendix $\mathrm{C}$ for the outcome of the Scheffe test.
}

\footnotetext{
11 See appendix B for more details on the use of Malmquist's methodology to estimate total productivity indices for factors, technical change and efficiency.
} 


\section{$\mathrm{V}$}

\section{Conclusions}

This paper is meant as a methodological and analytical contribution to a line of research whose objective is to construct representative indices of the technological capabilities of Mexican manufacturing firms, and its concern has been to study the distribution of these capabilities in a sample of establishments.

For the construction of representative technological capability indices, the use of factor analysis enabled us to simplify complex relationships into a small number of common factors (or dimensions) that are intertwined in them through apparently unrelated variables. The advantage of this approach compared to the calculation of a single index using a straightforward scoring system, which is what other authors have done, is that there is no need to assign subjective weightings and the task of determining the percentage of the variance that is explained by each factor can be left up to the factor analysis. This is one contribution of the present work.

In the case before us, following an exhaustive exploratory factor analysis it was possible to identify four factors expressing the main sources of learning in manufacturing: i) training policy, ii) continuous improvement innovation, iii) information and documentation systems, and iv) investment in new technologies.

The first factor, as its name suggests, expresses the institution of a training policy at every level in the company: managerial staff, clerical staff, skilled workers and general workers. A high degree of correlation is observed between these variables, suggesting that when a company has a training policy, it implements it at all levels.

The second factor relates to learning through continuous improvement. The presence of research and development activities in this group of variables suggests that, in Mexican industry, the aim of these activities is to assimilate, adapt and improve imported technology (as is the case in similar countries), and that innovation capabilities do not come in here. Learning activities are associated with exporting, our proxy variable for technological information obtained from customers abroad, as Yan Aw and Batra (1998) propose in the case of Taiwanese industry. In Mexico, the modernization process has involved firms in a concentrated problem-solving effort rather than in radical innovations, and this has resulted in changes to the organization of production operations. Again, firms are gradually moving towards what has been called a new culture of quality, involving international quality certification. Lastly, learning through contact with foreign customers as a result of exporting may suggest that the information flow achieved is linked to the continuous improvement innovation process, which in turn enables exports to grow.

The third factor identifies process documentation systems, written rules and company planning. It is not possible to take a long-term approach without having a selection of precise indicators that provide a basis for accurate analysis so that critical problems can be identified.

The fourth factor, lastly, expresses the technological effort from the point of view of hard technology use, i.e., the introduction of new technologies and the renewal of machinery.

Although our initial variables were selected following Lall's (1992) taxonomy, at the end of the analysis it was production capabilities that predominated. Where investment capabilities are concerned, mention should be made of technology purchasing, research and development, and the renewal of equipment and introduction of new technologies.

The results of the linkage variable, where relations with universities and research centres, subcontracting and joint ventures are concerned, undoubtedly reveal one of the greatest shortcomings in the innovation capabilities of Mexican companies. Progress has been made, partly because of the links forged by some companies with universities, which are not reflected at the sample level, but mainly because of contact with foreign customers through exporting.

To examine the distribution of capabilities in the sample we used cluster analysis, taking the score of each observation for each factor as the basis. Four clusters or groups of establishments were identified on the basis of their factorial capability indices. Group I presents three factors with positive levels: documentation and planning systems, the introduction of new technologies, and continuous improvement innovation. Group II exhibits vigorous training 
programmes and planning and documentation systems, followed by group III, which only has documentation and planning systems. Group IV displays negative levels for all three factors, i.e., it is the least advanced.

While it was to be expected that training would be found in group I, the companies in this group had a low training average; in our opinion, it is possible that they had carried out training in the past and that this was not reflected at the time of the interview; but in any event, where the second factor is concerned (continuous improvement innovation), these firms were found to have a policy of recruiting highly qualified staff. As already explained, the small number of establishments in group IV does not indicate that this is representative of industry, since the sample is skewed towards medium-sized and large enterprises. In a larger sample, the bottom group includes $41 \%$ of businesses. The evidence on structural underdevelopment in microenterprises and small businesses suggests that the largest percentage of firms in Mexican industry belongs to this cluster.

The characteristics of the clusters confirm the association between company size and technological capability levels. Our results cast an interesting light on the effects of foreign direct investment on these capabilities. It is clear that a large number of foreign enterprises belong to the group with the highest level of technological capabilities. But not all foreign firms have these characteristics, as is revealed by the large percentage of them located in group III.

Lastly, we need to return to our original argument regarding the importance of analysing the technological capability levels of different firms to attain a better understanding of their differences in the heterogeneous situation that characterizes developing economies. The analysis of performance indicators in the groups with different technological capability levels revealed an association between technological capabilities and performance in the case of labour productivity, profit margins and technical change. This indicates that technological capabilities, because of their effect on companies' innovation behaviour, have a positive influence on performance and help explain the differences found in this respect.

Given that performance averages decrease from group I to group IV, it is tempting to suggest that the distribution of these groups by factorial scores might reflect a pattern of capacity accumulation in firms. Acquiring technological capabilities by developing documentation and planning systems (group III) would seem to be the minimum necessary for learning; this would be followed, in ascending order, by in-house training programmes (group II), then by the most comprehensive learning effort involving continuous improvement innovation (group I), which in the case of Mexico includes research and development. The risk here is that the analysis may be too simplistic. The Scheffe test only supported this possible pattern of capability accumulation in the case of labour productivity and profit margins, where the differences between group I and the rest are significant. In the case of technical change, the large differences are between group IV (the lowest scoring) and the rest. Thus, there is scope for selecting corporate learning strategies that derive from the sectoral needs of firms, rather than progressing necessarily in defined stages. This line of research remains pending, however, and work needs to be done here. If it were shown, for example, that documentation were a first step, this might lead to technology and industrial policy setting the requisite priorities.

In any event, our results suggest a need to devise a technology policy to support the accumulation of technological capabilities in Mexican firms. Some progress has been made with support programmes, but their coverage is still inadequate. The results also show that very few of them have a comprehensive technological learning strategy. 
APPENDIX A

Methodology for constructing variables from the National Survey of Employment, Wages, Technology and Training (ENESTYC)

\begin{tabular}{|c|c|}
\hline Group & Variables \\
\hline $\begin{array}{l}\text { Learning and } \\
\text { investment }\end{array}$ & $\begin{array}{l}\text { Purchase of technology packages or transfer from } \\
\text { the parent company } \\
\text { Investments in management technology } \\
\text { Investments in basic engineering } \\
\text { Investments in patents } \\
\text { Policy of recruiting qualified staff for each level } \\
\text { of employment }\end{array}$ \\
\hline
\end{tabular}

\begin{tabular}{|c|c|c|c|}
\hline & & $\begin{array}{l}\text { required for managerial, } \\
\text { clerical and manual staff }\end{array}$ & $\begin{array}{l}\text { (post-secondary } \\
\text { qualification) } \\
\mathrm{w}=1 \\
\text { If clerical employees have } \\
\text { to have at least bachille- } \\
\text { rato } \\
\mathrm{x}=1 \\
\text { If manual workers (skilled } \\
\text { or general) have to have } \\
\text { complete secondary } \\
\text { education } \\
\mathrm{y}=1 \text { and } \mathrm{z}=1 \\
\text { Recruitment policy } \\
=\mathrm{w}+\mathrm{x}+\mathrm{y}+\mathrm{z} \\
\text { Maximum score }=4\end{array}$ \\
\hline Production & $\begin{array}{l}\text { Research and development applied to the } \\
\text { production process } \\
\text { Organization } \\
\text { (just-in-time production + production and process } \\
\text { control + rotation + plant lay-out + worker } \\
\text { participation + supervision + standards) } \\
\text { Quality } \\
\text { (quality circles + total quality control + } \\
\text { certification + instrumental c.) } \\
\text { Preventive and predictive maintenance approach } \\
\text { Documentation (norms + training) } \\
\text { Security } \\
\text { Introduction of new technologies: Buying-in of } \\
\text { technology } \\
\text { Intensity of training } \\
\text { (managerial staff, clerical staff, skilled workers, } \\
\text { general workers) }\end{array}$ & $\begin{array}{l}1=\text { yes } \\
1=\text { yes } \\
1=\text { yes } \\
1=\text { yes } \\
1=\text { yes } \\
1=\text { yes } \\
\text { CNC or robots }=1 \\
1=\text { yes } \\
\text { Number of employees } \\
\text { trained }\end{array}$ & $\begin{array}{l}\text { Maximum score }=4 \\
1.0 \\
1.0 \\
1.0 \\
1.0 \\
1=1 \% \text { to } 20 \% \\
2=20 \% \text { to } 39 \% \\
3=\text { over } 40 \%\end{array}$ \\
\hline Linkage & $\begin{array}{l}\text { Subcontracting } \\
\text { Linkage with universities } \\
\text { Joint ventures in: } \\
\text { Sales or procurement } \\
\text { Research and development } \\
\text { Training } \\
\text { Use and procurement of machinery and } \\
\text { equipment } \\
\text { Initiatives to link up with universities or other } \\
\text { institutions } \\
\text { Information flows from contacts with customers } \\
\text { abroad }\end{array}$ & $\begin{array}{l}1=\text { yes } \\
1=\text { yes } \\
1=\text { yes } \\
1=\text { yes } \\
1=\text { yes } \\
1=\text { yes } \\
1=\text { yes }\end{array}$ & 1 to 8 \\
\hline
\end{tabular}

Source: Prepared by the authors. 
APPENDIX B

\section{Malmquist index of total factor productivity}

The construction of this index is based on the concept of output distance functions. ${ }^{15}$ For each of the periods studied, technology $S^{16}$ is the set of inputs $\left(x^{t}=\left(x^{I}, \ldots \ldots \ldots, x^{N}\right)\right)$ and outputs $\left(y^{t}=\left(y^{1}, \ldots \ldots \ldots, y^{N}\right)\right)$. The output distance function in period $t$, expressed as $D_{0}^{t}\left(x^{t}, y^{t}\right),{ }^{17}$ measures the maximum expansion of output that can be achieved with a given input vector ${ }^{18}$ in relation to a frontier function. The output distance function for a given industry has a value of one when the output level is at the production frontier; it is less than one when the output level is below the frontier value and more than one when it is above this.

Similarly, the distance function $D_{1}^{t+1}\left(x^{t}, y^{t}\right)$ is the ratio between the output achieved in period $t$ and the maximum possible given the technology of the period $t+1$.

According to Caves, Christensen and Diewert (1982), the Malmquist index of total factor productivity between two periods, such as $t$ and $t+1$, can use the technology of either of the two years as a reference point. Taking the technology of year $t$ as a parameter, the index is as follows: $M_{i}^{t}=\frac{D_{0}^{t}\left(x^{t+1}, y^{t+1}\right)}{D_{0}^{t}\left(x^{t}, y^{t}\right)}$. When the parameter taken is the technology of the period $t+1$, the index is defined as follows: $M_{1}^{t+1}=\frac{D_{0}^{t+1}\left(x^{t+1}, y^{t+1}\right)}{D_{0}^{t+1}\left(x^{t}, y^{t}\right)}$. When $M>1$, this denotes a rise in productivity between $t$ and $t+1$ and when $M<1$ this denotes a drop in productivity.
Färe, Grosskopf and others (1994) showed that the Malmquist index could be regarded as a geometric mean of the two previous equations.

$$
M_{i}\left(y^{t+1}, x^{t+1}, y^{t}, x^{t}\right)=\left[\frac{D_{0}^{t}\left(y^{t+1}, x^{t+1}\right)}{D_{0}^{t}\left(y^{t}, x^{t}\right)}\right]\left[\frac{D_{0}^{t+1}\left(y^{t+1}, x^{t+1}\right)}{D_{0}^{t+1}\left(y^{t}, x^{t}\right)}\right]^{1 / 2}
$$

The index thus defined can be broken down into two parts: change in efficiency (approaching the frontier) and technical change (innovation). As follows:

$M_{0}\left(y^{t+1}, x^{t+1}, y^{t}, x^{t}\right)=\left[\frac{D_{0}^{t+1}\left(y^{t+1}, x^{t+1}\right)}{D_{0}^{t}\left(y^{t}, x^{t}\right)} x\right]\left[\left(\frac{D_{0}^{t}\left(y^{t+1}, x^{t+1}\right)}{D_{0}^{t+1}\left(y^{t+1}, x^{t+1}\right)}\right)\left(\frac{D_{0}^{t}\left(y^{t}, x^{t}\right)}{D_{0}^{t+1}\left(y^{t}, x^{t}\right)}\right]^{1 / 2}\right.$

The method allows for the possibility of working with constant scale and variable yields. Constant scale yields are appropriate when it is assumed that all companies produce at an optimum scale. However, imperfect competition and other obstacles, such as financial ones, mean that establishments do not produce at this optimum scale. When companies do not have optimum scales and constant scale yields are assumed, technical change is confused with scale efficiencies. To separate the scale effect from technical change it is necessary to calculate the index of technical change in accordance with the assumption of constant and variable scale yields. The difference between these two indices reveals a scale efficiency or inefficiency.

APPENDIX C

Analysis of one-way variance: the Scheffe test

\begin{tabular}{lcccccc}
\hline Group & Group & $\begin{array}{c}\text { Total factor } \\
\text { productivity }\end{array}$ & $\begin{array}{c}\text { Technical } \\
\text { change }\end{array}$ & Efficiency & $\begin{array}{c}\text { Labour } \\
\text { productivity }\end{array}$ & Margin \\
\hline I & II & 0.954 & 0.767 & 0.988 & 0.123 & 0.348 \\
& III & 0.828 & 0.907 & 0.0762 & 0.000 & 0.001 \\
& IV & 0.324 & 0.120 & 0.730 & 0.000 & 0.000 \\
II & I & 0.954 & 0.767 & 0.988 & 0.123 & 0.348 \\
& III & 1.000 & 0.513 & 0.992 & 0.900 & 0.878 \\
& IV & 0.855 & 0.011 & 0.964 & 0.118 & 0.403 \\
III & I & 0.828 & 0.907 & 0.762 & 0.000 & 0.001 \\
& II & 1.000 & 0.513 & 0.992 & 0.900 & 0.878 \\
& IV & 0.728 & 0.063 & 0.990 & 0.141 & 0.626 \\
IV & I & 0.324 & 0.012 & 0.730 & 0.000 & 0.000 \\
& II & 0.855 & 0.011 & 0.964 & 0.118 & 0.403 \\
& III & 0.728 & 0.063 & 0.990 & 0.141 & 0.626 \\
\hline
\end{tabular}

Source: Prepared by the authors using information from the National Survey of Employment, Wages, Technology and Training (ENESTYC).

\footnotetext{
${ }^{15}$ See Färe, Grosskopf and others (1994) and Caves, Christensen and Diewert (1982).

${ }^{16} \mathrm{~S}$ is a non-empty, closed, convex set, and it is also assumed that both inputs and outputs are freely available.

17 The formal definition of the production frontiers is: $D_{0}^{t}\left(x^{t}, y^{t}\right)$ $=\min \left\{\Theta:\left(x^{t}, y^{t} / \Theta\right) S^{t}\right\}, x^{t} \varepsilon \mathrm{R}^{\mathrm{N}}, t=(1, \ldots, T)$. In other words
}

the distance $\Theta$ is the ratio between observed output and the maximum possible, for a given level of inputs. See Färe and Grosskopf (1988). ${ }^{18}$ Distance functions can also be expressed in terms of inputs. These functions measure the maximum possible reduction in inputs for the same level of output. 
Amsden, A. (1992): Asia's Next Giant: South Korea and Late Industrialized Countries, New York, Oxford University Press.

Bell, M. and K. Pavitt (1992): Accumulating technological capability in developing countries, Proceedings of the World Bank Annual Conference on Development Economics, Washington, D.C., World Bank.

Cantner, U. and H. Hanusch (2001): Heterogeneity and evolutionary change: empirical conception, findings and unresolved issues, in J. Foster and S. Metcalfe, Frontiers of Evolutionary Economics, Competition, Self-organization and Innovation Policy, Northampton, Edward Elgar.

Carrillo, J. (1993): La Ford en México: reestructuración industrial y cambio en las relaciones sociales, thesis, Mexico City, El Colegio de México.

Casas, R., R. de Gortari and M. Luna (2000): University, knowledge production and collaborative patterns with industry, in M. Cimoli, Developing Innovation Systems: Mexico in a Global Context, London, Continuum.

Caves, D.W., L.R. Christensen and W.E. Diewert (1982): The economic theory of index numbers and the measurement of input, output and productivity, Econometrica, vol. 50, No. 6, Evanston, The Econometric Society.

Cimoli, M. (2000): Developing Innovation Systems: Mexico in a Global Context, London, Continuum.

Coriat, B. (1992): Pensar al revés, Mexico City, Siglo XXI.

Dillon, W. and M. Goldstein (1984): Multivariate Analysis, Methods and Applications, New York, John Wiley \& Sons.

Dutrenit, G. and M. Capdevielle (1993): El perfil tecnológico de la industria mexicana y su dinámica innovadora en la década de los ochenta, El trimestre económico, vol. 60(3), No. 239, Mexico City, Fondo de Cultura Económica, July/September.

Edquist, Ch. (1992): Technological and organizational innovations, productivity and employment, Working Paper, No. 233, Geneva, World Employment Programme, International Labour Organization (ILO).

Färe, R. and S. Grosskopf (1988): Fundamentals of Production Theory, Berlin, Springer-Verlag.

Färe, R., S. Grosskopf and others (1994): Productivity growth, technical progress, and efficiency change in industrialized countries, American Economic Review, vol. 64, Nashville, Tennessee, American Economic Association.

Fransman, M. and K. King (eds.) (1984): Technological Capability in the Third World, London, Macmillan.

Hoffman, K. (1989): Technological Advance and Organizational Innovation in the Engineering Industry: A New Perspective of the Problems and Possibilities for Developing Countries, Industry Series Paper, No. 4, Washington, D.C., World Bank.

Katz, J. (1987): Technology Generation in Latin American Manufacturing Industries: Theory and Case Studies Concerning its Nature, Magnitude and Consequences, London, Macmillan.
(1997): New problems and opportunities for industrial development in Latin America, Oxford Development Studies, vol. 25, No. 3, Oxford, Taylor \& Francis Group.

Lall, S. (1992): Technological capabilities and industrialization, World Development, vol. 20, No. 2, Amsterdam, Elsevier Science, February.

Lall, S. and others (1994): Technology and Enterprise Development: Ghana Under Structural Adjustment, London, Macmillan.

Lundvall, B. (1992): National Systems of Innovation: Towards a Theory of Innovation and Interactive Learning, London, Printer Publishers.

Nelson, R. and S. Winter (1982): An Evolutionary Theory of Economic Change, Cambridge, Massachusetts, Harvard University Press.

Pack, H. and L. Westphal (1986): Industrial strategy and technological change: theory versus reality, Journal of Development Economics, vol. 22, No. 1, Amsterdam, Elsevier Science.

Pavitt, K. (1984): Patterns of technical change: towards a taxonomy and a theory, Research Policy, vol. 13, No. 6, Amsterdam, Elsevier Science.

Romijn, H. (1999): Acquisition of Technological Capability in Small Firms in Developing Countries, London, Macmillan.

Schilderinck, J. (1970): Factor Analysis Applied to Developed and Developing Countries, Rotterdam, Rotterdam University Press.

Tabachnick, B. and L. Fidell (2001): Using Multivariate Statistics, Boston, Allyn and Bacon.

Tremblay, P. (1998): Technological Capability and Productivity Growth: An Industrialized /Industrializing Country Comparison, Montreal, Centre Interuniversitaire de Recherche en Analyse des Organisations.

Westphal, L. and others (1990): The development of technological capability in manufacturing: a macroscopic approach to policy research, in R. Evenson and G. Ranis, Science and Technology: Lessons for Development Policy, London, Intermediate Technology Publications.

Westphal, L., Y. Rhee and G. Pursell (1984): Sources of technological capability in South Korea, in M. Fransman and K. King, Technological Capability in the Third World, London, Macmillan.

Wignaraja, G. (1998): Trade Liberalisation in Sri Lanka: Exports, Technology and Industrial Policy, London, Macmillan. (2001): Firm Size, Technological Capabilities and Market Oriented Policies in Mauritius, Discussion Papers, No. 1, Maastricht, United Nations University (UNU)/Institute for New Technologies.

Yan Aw, B. and G. Batra (1998): Technological capabilities and firm efficiency in Taiwan (China), World Bank Economic Review, vol. 12, Washington, D.C., World Bank. 